\title{
Do Australian Firms Undertake Too Little Research and Development?
}

\author{
Scott Mitchell
}

$\mathrm{I}$

$\mathrm{N}$ recent times, Australia has spent less on R\&D (as a proportion of GDP) than all but half a dozen of the OECD and ASEAN nations. This shortfall is not due to public $R \& D$ expenditure, which is the fourth-highest in the OECD/ASEAN group. Rather, it reflects the fact that Australian companies carry out significantly less R\&D than their overseas counterparts. Of the 23 nations listed in the 1994 edition of the OECD's Main Science and Technology Indicators (1994), only five spent less on business R\&D than Australia (see also Figure 1).

None of this means that Australia undertakes too little private R\&D. Australia could even be undertaking too much research for a resource-based economy. In order to determine whether Australia's R\&D effort is appropriate, it is necessary to ascertain what drives innovation, and to what extent these forces may be distorted. This article argues that competition drives innovation, and that protectionist policies have held back Australia's R\&D effort.

Business innovation matters. Most growth in real GDP per head has come from technological change, which in tum is due to product, process or organisational innovation. For most of this century, Australia's real per capita growth rates have been below the OECD average, perhaps because Australia's expenditure on business R\&D has also been below the OECD average as far back as statistics are kept (Price Waterhouse, 1985). As Figure 1 indicates, innovation undertaken by private firms appears to have a significantly stronger effect on productivity than does government R\&D. In countries like Australia, where business innovation is low, government innovation tends to be high, but with seemingly little effect on productivity. Perhaps public research has been driven more by scientific priorities than by industry requirements.

\section{Why Does Australia Innovate Less?}

Since a high proportion of its industries are characterised by low returns to $R \& D$, Australia could be expected to undertake less imnovation than other OECD nations. Manufacturing, usually the most R\&D-intensive sector, is smaller in Australia than in most OECD countries. High-technology industries, which usually invest heavily in $R \& D$, are a smaller proportion of manufacturing in Australia than in many de-

Scott Mitchell is an economist in the Commonwealth Treasury and a postgraduate student in economic history at The Australian National University. 
veloped nations. However, even taking into account such structural considerations, Australia's business expenditure on R\&D is still comparatively low (Hall, 1993).

\section{Figure 1}

\section{Contributions of business and government R\&D to productivity, by OECD country relative to average, 1991}

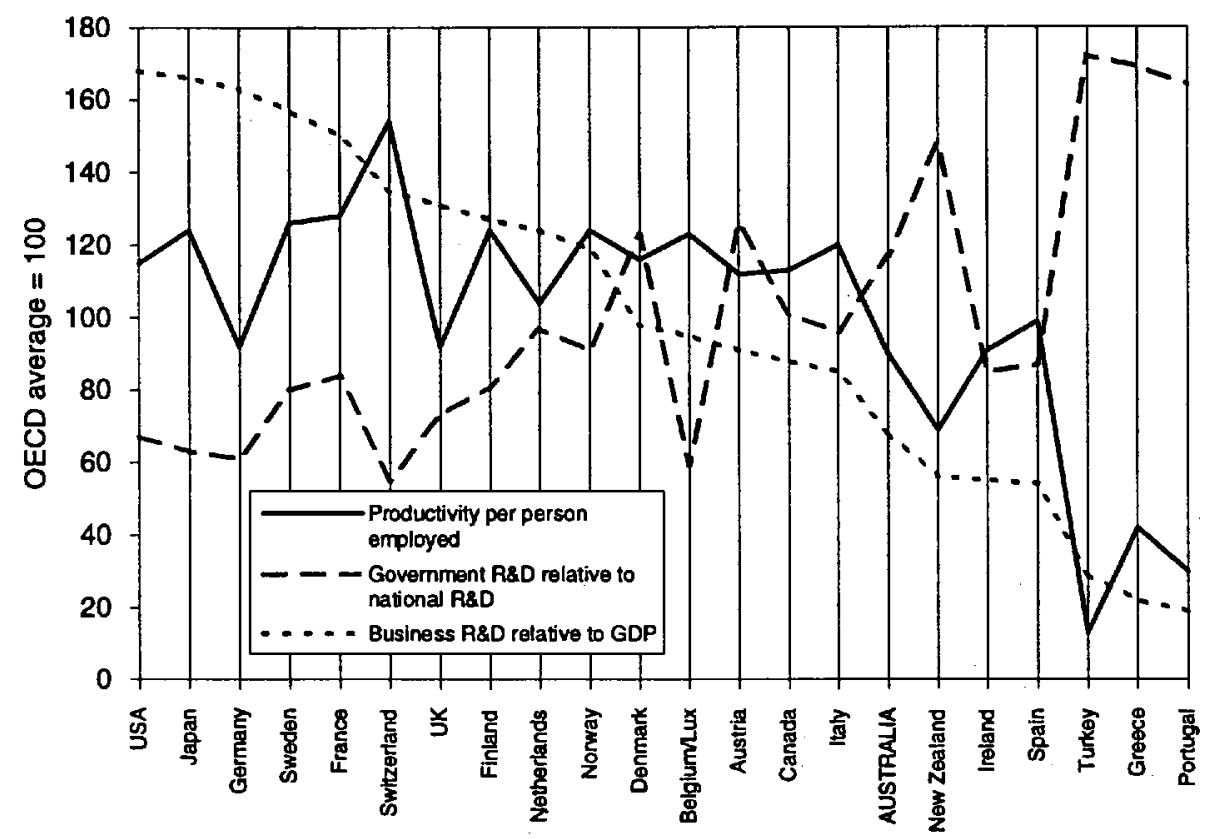

Source: EMF Foundation (1993).

Innovation in Australia may be low also because of 'spillovers', which allow firms to benefit freely from one another's research efforts. But it is equally possible that government intervention may overcompensate for the effects of spillovers. There appears to be no strong evidence to show that spillovers are greater in Australia than in other OECD nations (IC, 1995); yet the Australian government's supply of basic $R \& D$ to the private sector represents one of the largest public-sector R\&D programs in the OECD. Financial assistance to private innovation is also generous. For example, business R\&D expenditure is allowed a 150 per cent tax deduction in Australia, a considerably higher amount than in most countries.

Another possible reason for Australia's low levels of innovation is that it may be cheaper to import new techmology than to develop it domestically. The theory of comparative advantage suggests that a country is best off if it concentrates on those goods and services it can produce most efficiently and imports other goods and 
services. However, while it can be relatively easy to acquire the technology itself, it may be difficult to understand, modify, or even use it without a knowledge of how it was developed. It is difficult to acquire this knowledge separately, since information cannot be easily bought and sold. The classic problem of information is that people are unwilling to buy it without knowing what it is, and then unwilling to pay for it once they do know. Even if they were willing, much of the knowledge gained from innovation does not exist in a tradable form. It is often tacit rather than explicit, residing in a firm's collective memory rather than its blueprints. In other cases, the required knowledge may simply not be available elsewhere - or its possessors have not revealed its existence to potential competitors. Finally, if a firm does acquire the information it needs, it may be unwilling to invest in sufficient in-house research to enable it to understand it.

These factors explains why very few Australian companies' innovative technologies are developed from sources outside the firm: the Bureau of Industry Economics (BIE) (1993) found that 79 per cent of innovations used by Australian firms were sourced from within the firm itself. For the same reasons, that there are few firms specialising in supplying research for other companies.

\section{Innovation and Theories of Growth}

Apart from the structural, spillover and comparative advantage factors, orthodox neoclassical theory has little to say about why one nation (or firm) may undertake more or less R\&D than another. The standard model assumes diminishing returns to capital: the more a firm increases its capital in proportion to its labour, the smaller the increases in output it will obtain. Yet a cursory glance at history shows that increasing capital intensity has been raising output for at least the last 1,000 years (see, for example, Snooks, 1993). When neoclassical theory is applied to realworld data, all the observed increases in outputs in excess of increases of inputs have to be put in a residual column, usually titled 'Total Factor Productivity' and attributed to innovation; but there is nothing in the theory as to how, when, where or why such innovation might occur.

The foremost attempts to include growth in neoclassical models are by Solow (1956) and Swan (1956). But though mathematically elegant, such models have managed only to duplicate retrospectively given real-world outcomes. As there has been little replication of real-world processes, these models have had little predictive power or usefulness for policy. As Snooks (1993:83) notes:

... even though technological change was more clearly specified ... it was not treated endogenously but rather grafted awkwardly on to the body of these growth models.

One of these models, the recent 'New Growth Theory', does away with the central 'stagnation' of neoclassical theory and permits growth to occur through increasing returns to scale. However, while this model allows technical change to occur, it still sheds little light on what drives innovation. 
To ascertain what drives R\&D and why Australia has undertaken so little, it is necessary to venture outside the world of maths-based theories and to look instead at theories derived from observations of real-world innovation.

\section{Theories of Innovation}

Arguably the two best-known innovation theories are those of Jacob Schmookler and Joseph Schumpeter. Schmookler (1966), after studying over 1,000 innovations, rejected the 'science-push' theory of innovation. This earlier theory held that scientists make serendipitous breakthrouglıs, which businesspeople can then develop and sell. Schmookler found that all but a handful of innovations came about as a result of research directed at identified market needs. His 'market-pull' theory argues that innovation is driven by market demand: firms develop new products if the estimated profits exceed the estimated development costs.

However, Schmookler's theory does not appear to hold in the Australian case. Demand for new technology is high in Australia; there are more mobile phones, faxes, videos, PCs and internet accounts per head in Australia than all but one or two nations in the world. Yet on the supply side there is little innovation. Perhaps the shortcoming in Schmookler's theory lies in the relative ease of innovation: in his theory, firms face few transaction costs, but simply draw what they need from a pool of scientific knowledge and develop a new product that will meet the identified needs.

Schumpeter $(1934,1942)$, in contrast, recognises that innovation has very high transaction costs. Innovation is a 'strongly uncertain' activity. An event is considered to involve risk if both the outcomes and their probabilities are known (for example, rolling a die). It is uncertain if only the events are known but not the probabilities (for example, whether the dollar will rise or fall tomorrow). It is strongly uncertain if neither the events nor their probabilities are known (for example, what will happen if I mix several unknown chemicals). Not only is innovation strongly uncertain, but the factors affecting it are manifestly complex. For example, 'pure' information (which often resides only in humau memory bauks) can be dependent on the current state of the various scientific disciplines and institutions, the apparatus for transferring information, the numbers and types of knowledge bases and the search procedures used to glean them. Similarly, 'embodied' information (technology) is more complex than Sclimookler assumes. In reality, a firm cannot produce an innovation by just dipping into the available pool of technologies whenever it detects a new demand; it has to learn how to use existing technologies before it can combine them in new forms. Further, no existing mechanism is efficient at dealing with the uncertainties and complexities of innovation. As discussed above, there are often prohibitively high transaction costs to acquiring information through the market. Although the state undertakes vast amounts of research, little useful information crosses the cultural divide between it and private firms (which is why joint government and private Cooperative Research Centres have recently been set up in Australia). 
Schumpeter found that, because of all these uncertainties, complexities and other difficulties, imnovation is driven by competition: most firms' managers were unwilling to engage in innovation unless they really had to. Exceedingly large potential profits would be required to act as an incentive to innovation, for several reasons. First, strong uncertainty requires much greater potential returns to yield positive expected values than does mere risk (venture capitalists operate in the hope that one wildly successful project in every few hundred will recoup the costs of all the others). Second, innovation tends to be expensive. A widely quoted rule in industry is that for every dollar spent on research, ten need to be spent on development and a hundred on commercialisation. The BIE (1993) surveys confirmed this rule for major R\&D projects on manufacturing. ${ }^{1}$ For a given degree of risk, the greater the sums involved, the greater is the return needed to make a project attractive: people will chance $\$ 20$ on an even bet, but they won't risk their company on one. Given that managers (like most people) are risk-averse, it will often be entirely rational not to invest in innovation.

Schumpeter noted that firms' incentives to imnovate decreased as profits increased. Only when profits are reduced by competitors will firms be driven to innovate. Even firms that once innovated under competitive pressure often cease doing so once they can shelter their profits behind their innovations. For example, IBM originally became involved in computers only because it feared that competitors might use them to threaten its core business of census tabulating. Later, feeling safe behind its mainframe liegemony, IBM did not bother to undertake the R\&D for its new personal computers but paid Intel and Microsoft to do so.

\section{Innovation and Competition}

As well as being intuitively plausible, Schumpeter's theory is testable. If we can establish that competition drives imovation, and that there is a sub-optimal degree of competition, then, other things being equal, we can establish whether or not there is a sub-optimal level of innovation.

We know that innovation lias been low in Australia. We know also that there have been many impediments to competition, both domestic and trade-related, in Australia; that these impediments liave been reduced over the last 20 years; and that business R\&D has been increasing. Moreover, several authors have tested - and confirmed - Schumpeter's theories in other countries (see, for example, Grabowski \& Baxter, 1973; Gort \& Konakayama, 1982; Montgomery \& Wascher, 1988). What does the qualitative and quantitative evidence indicate for Australia?

As noted above, a number of mathematically sophisticated, but policyredundant, models of imnovation and growth liave been developed. Hence, before conducting any statistical analysis, it is worth examining the insights of those who have been involved in innovation in Australia. As those in applied market research say: 'If a number seems right, it probably is'.

\footnotetext{
${ }^{1}$ However, because much innovation involves only increments to established processes, the total ratio of research to development and commercialisation is around one to two (see ABS, 1995).
} 
Many researchers have noted that the 'institutionalised uncompetitiveness' that results from tariff walls has had a detrimental effect on innovation. Brian Hickman, who heads the ARC's efforts to encourage collaborative research between universities and industry commented:

... the major problem has been that until recently, the whole economic environment in which industry has been operating has not encouraged innovation. But change has been forced in this situation in the last five years by the greater degree of international competitiveness that is being forced on industry [which is] providing encouragement to innovation. (IC, 1993:870)

Similarly, Peter Hall (1992:14) observes that protectionist policies 'have reinforced preexisting conditions in Australia to influence firms and markets to interact in ways which, until recently, have created a range of negative feedbacks in relation to the effective development and application of new technology'. Manufacturers have noticed this too. The Business Council of Australia also found that increased competition is having a significant effect on imovation. After interviewing 700 CEOs of Australian firms for its 1993 study Managing the Imnovative Enterprise, the Council concluded that: "The internationalisation of the Australian economy and the new performance standards it requires are the predominate drivers of enterprise innovation' (Camegie, 1993:331). Indeed, noting that a number of 'now strong and successful' enterprises such as Comalco, Toyota, Ericsson and Du Pont had faced a 'very serious' risk of closure not long ago because of cuts in protection, the Council observed: 'Tariff reductions, and warnings of tariff reductions to come, figure among the most effective triggers for improvement among the enterprises the Study Commission saw' (Carnegie, 1993:80). The BIE (1993), in its survey of 900 firms, found that the need 'to create a competitive advantage' was the foremost influence on R\&D expenditure. Market opportunities (Sclumookler's 'demand-pull') had a significantly lower impact on innovation decisions. Technological changes, or 'science push', had only about the same influence as subsidies.

So both those who practise and those who observe imnovation in Australia consider that removing protection has given firms much greater incentive to innovate. The numbers seem to bear this out. Figure 2 shows that since the protection afforded by tariffs began to decrease in the mid-1970s, business R\&D has steadily increased. However, a number of factors other than increased competition might have had an impact on R\&D in Australia. Government subsidies for business R\&D have increased considerably over this period, most of it in the form of a 150 per cent tax concession for business $R \& D$, which was introduced in the mid-1980s. ${ }^{2}$ The BIE (1993) estimated that the subsidy provided under the Tax Concession is

\footnotetext{
2 The other main sulusidies are grants for specilic projects, which, having changed little, are unlikely to account for the significant increase in R\&D.
} 
equivalent to approximately 20 per cent of total business expenditure on $R \& D$, and has led to an increase in business expenditure on $R \& D$ of around the same order.

Figure 2

\section{Effective protection and business R\&D in Australia relative to 1985 levels, $1973 / 74-1990 / 91$}

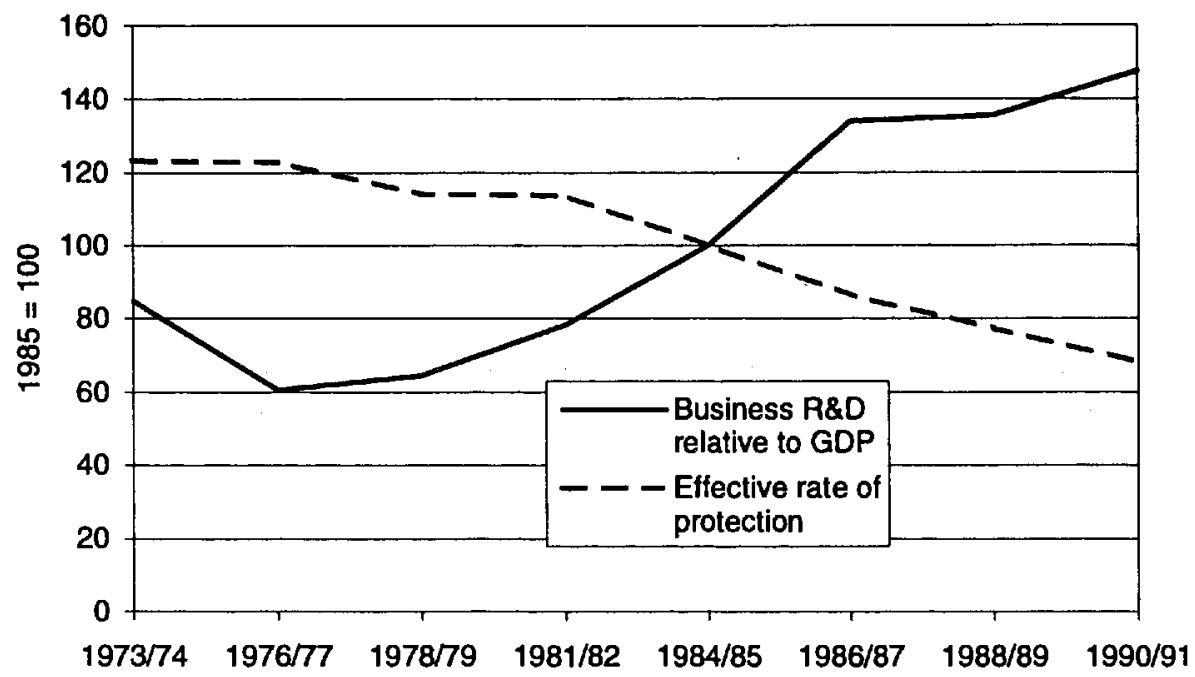

Sources: ABS (various years a, b, c); IC (various years).

Profits have also increased significantly since tariff reform. Could they be driving up R\&D? The Department of Industry, Science and Technology (DIST) often argued that firms needed subsidies because it was hard to finance innovation privately in Australia; with their newfound profits, firms now have more resources to devote to R\&D should they want to (see, for example, DIST, 1992). On the other hand, DIST's research arm, the BIE (1993), found that retained profits and cashflow were fairly low-order motivations for R\&D. It seems odd that profits have risen since competition has increased. Perhaps new competition drives R\&D, which then increases profits. A complementary possibility is that rents may have been larger before competition, but were dissipated by workers and management ' $\mathrm{X}$ inefficiency' - and did not appear as accounting profits.

Statistical analysis can often be useful for answering questions like the extent to which tariffs, profits or tax concessions drive R\&D. However, one reason economists have neglected imovation is the poor quality of the available data. In Australia, such historical data as exists have been collected only infrequently (nine times to 
date) and irregularly. Any results gleaned from statistical analysis must therefore be treated with considerable caution.

\section{A Statistical Test}

This article uses a time-series regression $\operatorname{model}^{3}$ to test to the effects of profits, ${ }^{4}$ tariffs and taxes on R\&D for the Australian manufacturing sector as a whole and its eleven Australian Standard Industrial Classifications (ASIC) subdivisions from $1973 / 74$ to $1990 / 91$. The manufacturing sector was chosen because, unlike the mining sector, it was greatly favoured by tariffs and lost from their removal; the vast majority of R\&D in manufacturing is carried out by private enterprise, unlike agriculture; and manufacturing accounts for the most business innovation in Australia.

Tariffs were chosen as a proxy variable for competition, and measured by Industry Commission (various years) estimates of effective rates of protection. As noted above, while there are many other forms of protection, tariffs have probably accounted for most of the changes in the period covered. This is not to say that effective protection is a good proxy for competition, but it is one that lends itself to being modelled.

The Tax Concession was measured using the BIE's (1993) estimates of nominal percentage rate of subsidy. Profits were measured as a ratio of Gross Operating Surplus to Gross Domestic Product from ABS (various years a, various years b). R\&D was measured as a percentage of Business Expenditure on Research and Development (BERD) to Gross Domestic Product, from ABS (various years c).

The model accurately simulated the observed clianges in business R\&D in the manufacturing sector. The regression of tariffs, tax concession and profits against $\mathrm{R} \& \mathrm{D}$ had a 'goodness of fit' (or $\mathrm{R}^{2}$ ) of .97 , indicating that changes in these three variables 'explained' nearly all of the changes in R\&D (see Table 1). ${ }^{5}$ This establishes that the overall model fits the facts well enough to test the thesis.

The results for manufacturing as a whole support the thesis that competition drives innovation. First, the results for tariffs showed that, as effective protection decreased, BERD increased. While the impact of protection on R\&D was not a strong one, it was statistically significant. Second, some support for the thesis was also obtained from the results on profits. Although not significant, the sign on the profit variable was negative, indicating that higher profits tend to be associated with diminished incentives to invest in R\&D, as Schumpeter predicted.

\footnotetext{
${ }^{3}$ While panel or pooled data may be preferable to a time series, this would require the assumption that the sensitivity of output to R\&D is the same across industries and over time, which is unlikely (see Bernstein \& Nadiri, 1989).

4 There may be an endogeneity problem to the extent that this period's profits are influenced by this periol's R\&D (although the correlation is under 0.10 in most cases). Lagged profits could be a suitable substitute but for the lengthy and variable lag.

${ }^{5}$ Most Durbin-Watson statistics were between 1.8 and 2.5 , which indicates the ligh $\mathbf{R}^{2} \mathrm{~s}$ are probably not due to regressing dillerence stationary variables.
} 
Table 1

Impacts of profits, tariffs and tax concessions on R\&D, by industry

\begin{tabular}{|c|c|c|c|c|}
\hline Industry & $\mathbf{R}^{2}$ & $\begin{array}{l}\text { Profit } \\
\text { (xioo) }\end{array}$ & $\begin{array}{l}\text { Tariff } \\
(x 100)\end{array}$ & $\begin{array}{l}\text { Tax concessions } \\
(\mathbf{x}(00)\end{array}$ \\
\hline Food, beverages \& tobacco & .91 & $\begin{array}{l}-0.80 \\
(-0.6)\end{array}$ & $\begin{array}{l}-0.01 \\
(-0.1)\end{array}$ & $\begin{array}{l}1.84 \\
(2.7)\end{array}$ \\
\hline Textiles, clothing \& footwear & .66 & $\begin{array}{l}0.16 \\
(0.1)\end{array}$ & $\begin{array}{l}-0.11 \\
(-0.7)\end{array}$ & $\begin{array}{l}0.66 \\
(0.7)\end{array}$ \\
\hline $\begin{array}{l}\text { Wood, wood products \& } \\
\text { furniture }\end{array}$ & .93 & $\begin{array}{l}-0.21 \\
(-0.2)\end{array}$ & $\begin{array}{l}0.18 \\
(0.2)\end{array}$ & $\begin{array}{l}0.75 \\
(3.2)\end{array}$ \\
\hline Pulp \& paper products & .76 & $\begin{array}{l}-1.40 \\
(-0.8)\end{array}$ & $\begin{array}{l}-1.40 \\
(-1.2)\end{array}$ & $\begin{array}{l}0.25 \\
(0.3)\end{array}$ \\
\hline Chemicals, petroleum \& coal & .93 & $\begin{array}{l}-0.28 \\
(-0.1)\end{array}$ & $\begin{array}{l}-4.51 \\
(-1.2)\end{array}$ & $\begin{array}{l}2.69 \\
(1.6)\end{array}$ \\
\hline Non-metallic mineral products & .88 & $\begin{array}{l}1.86 \\
(1.9)\end{array}$ & $\begin{array}{l}3.56 \\
(0.6) \\
\end{array}$ & $\begin{array}{l}0.92 \\
(1.8)\end{array}$ \\
\hline Basic metal products & .85 & $\begin{array}{l}1.03 \\
(0.7) \\
\end{array}$ & $\begin{array}{l}0.25 \\
(0.1)\end{array}$ & $\begin{array}{l}2.23 \\
(2.5)\end{array}$ \\
\hline Fabricated metal products & .83 & $\begin{array}{l}-1.53 \\
(-1.1)\end{array}$ & $\begin{array}{l}-0.87 \\
(-0.9)\end{array}$ & $\begin{array}{l}0.98 \\
(1.3)\end{array}$ \\
\hline Transport equipment & .90 & $\begin{array}{l}10.21 \\
(1.8)\end{array}$ & $\begin{array}{l}0.21 \\
(0.1)\end{array}$ & $\begin{array}{l}7.48 \\
(3.1)\end{array}$ \\
\hline Other equipment & .92 & $\begin{array}{r}-0.12 \\
(0.0)\end{array}$ & $\begin{array}{l}-2.86 \\
(-0.3)\end{array}$ & $\begin{array}{c}14.72 \\
(3.3)\end{array}$ \\
\hline Miscellaneous n.e.c. & .97 & $\begin{array}{l}0.93 \\
(0.9)\end{array}$ & $\begin{array}{l}-1.61 \\
(-1.0)\end{array}$ & $\begin{array}{l}1.81 \\
(3.2)\end{array}$ \\
\hline Total manufacturing & .97 & $\begin{array}{l}-1.37 \\
(-0.8)\end{array}$ & $\begin{array}{l}-6.79 \\
(-2.7)\end{array}$ & $\begin{array}{r}1.48 \\
(1.4)\end{array}$ \\
\hline
\end{tabular}

Notes: $\mathrm{A}^{2}$ indicates the extent to which change in A\&D is 'explained' by cumulative changes in profits, tariffs and tax concessions. The coefficients for these variables show how much a unit change in each will change R\&D. For example, a 1 per cent increase in effective subsidies from the tax concession should lead to a 0.15 per cent increase in R\&D to gross product. The figures in brackets are 4 ' statistics, which indicate the probability of a statistically significant relationship between the dependent variable and R\&D. In this particular case, a $t$ statistic greater than 1.53 indicates a 90 per cent probability, and one greater than 2.13 indicates a 95 per cent probability.

These results for the manufacturing subcategories also lend some support to the thesis. Not many variables appear as statistically significant, but, with such few observations, only comparatively strong relationships would do so. (A better proxy for competition than tariffs may be needed to show a stronger relationship.) The coefficients did, however, tend to have the right signs. R\&D increased as tariffs decreased in eight of the eleven ASIC three-digit manufacturing industries. Profits similarly had an inverse effect on R\&D in eight of the eleven industries. 
The model tended to be most supportive of the thesis in sectors that were innovative or competitive, and least supportive in those that were neither. For example, sectors with high R\&D intensities such as Other Equipment ${ }^{6}$ and Chemicals, Petroleum \& Coal had some of the strongest coefficients on effective rates. The regression also had its best fit with these sectors. Conversely, those sectors with the highest tariffs, such as Textiles, Clothing \& Footwear and Transport Equipment, had some of the weakest relationships between competition and R\&D. Textiles, Clothing \& Footwear was also the sector the model fitted least well.

Finally, although it was not significant for total manufacturing, the tax concession variable tended to have the strongest coefficient and the highest degrees of significance for all categories.

\section{Conclusion}

Schumpeter's thesis that competition drives innovation is supported by the qualitative evidence, and appears to be supported by such quantitative evidence as exists in Australia. It is widely accepted that restrictions on competition have damaged efficiency in a static sense by reducing firms' incentives to choose the lowest-cost combinations on their production frontiers. This article's findings may indicate that restrictions on competition in Australia have also damaged efficiency in a dynamic sense by reducing firms' incentives to shift their production frontiers. Hence, to the extent that Australia's below-average business expenditure on $R \& D$ is caused by its above-average levels of protection, Australia has indeed undertaken 'too little' R\&D.

Continuing to increase competition would appear to be the most effective policy to overcome these sub-optimal levels of innovation. Fortunately, this is happening. However, should the government retain obstacles to competition (like those in the labour market, for example), then using tax concessions to fund more business $R \& D$ may be a second-best solution.

${ }^{6}$ This category is R\&D-intensive due to computer software, which accounts for over 20 per cent of all Australian business R\&D. 


\section{References}

Australian Bureau of Statistics (ABS) (various years a), Australian National Accounts: National Income, Expenditure and Product, AGPS, Canberra (Cat. No. 5204).

- (various years b), Australian National Accounts: National Income, Expcnditure and Produch, AGPS, Canberra (Cat. No. 5206).

— (various years c), Reseanch and Experimental Development, Business Enterprises, Australia, AGPS, Canberra (Cat. No. 8104).

(1995), Innovation in Australian Manufacturing 1994, AGPS, Canberra (Cat. No. 8116 ).

Bernstein, J. \& M. Nadii (1989), 'Rates of Return on Physical Capital and R\&D Capital and Structure of the Production Process: Cross Section and Time-series Evidence', in Advances in Econometrics and Modelling, Kluwer, London.

Bureau of Industry Economics (BIE) (1993), R\&D, Innovation and Competitiveness: An Evaluation of the Research and Development Tax Concession, AGPS, Canberra (Research Report No. 50).

Cannegie, R. (1993), Managing the Imuovative Enterprise: Australian Companies Competing with the World's Best, Business Council of Australia, Melbourne.

Department of Industry, Science and Technology (DIST) (1992), 'DrTAC/IR\&D Board Submission to Industry Commission Inquiry into the National Development Procurement Program', Canberra.

- (1994), Australian Science and Imnovation Resources Brief 1994, AGPS, Canberra.

EMF Foundation (1993), World Competitiveness Report 1993, Switzerland.

Gort, M. \& A. Konakayama (1982), 'A Model of Diffusion in the Production of an Innovation', American Economic Review 72(5): 1111-20.

Grabowski, H. \& N. Baxter (1973), 'Rivalry in Industrial Research and Development - an Empirical Study', Joumal of Industrial Eronomics: 23: 209-35.

Hall, P. (1992), 'The Domestic Economic Context for Scientific and Technological Development in Australia', paper presented to the Conference on Intenational Dimensions of Australian Scientific and Technological Development, University College, UNSW, Canberra, October.

Industy Commission (IC) (various years), Annual Report, AGPS, Canberra.

- (1994), 'Transcript of Proceedings, Inquiry into Research and Development', Spark and Cannon, Canberra (November).

— (1995), Research and Development, AGPS, Canberra (Report No. 44).

Montgomery, E. \& W. Wascher (1988), 'Creative Destruction and the Behaviour of Productivity over the Business Cycle', Review of Economics and Statistics 70(1): 168-72.

Organization for Economic Cooperation and Development (OECD) (1994), Main Scjence and Technology Indicators, Paris.

Price Waterhouse (1985), The Promotion of Indigenous IR\&D in Australia and the Effectiveness of the Industrial Research and Development Incentives Scheme, Canberra. 
164 Scott Mitchell

Schmookler, J. (1966), Invention and Economic Growth, Harvard University Press, Cambridge, Mass.

Schumpeter, J. (1934), The Theory of Economic Development, Harvard University Press, Cambridge, Mass.

- (1942), Capitalism, Socialism and Democracy, McGraw-Hiil, New York.

Snooks, G. (1993), Economics without Time, Macmillan, London.

Solow, R. (1956), 'A Contribution to the Theory of Economic Growth', Quarterly Journal of Economics 70: 65-94.

Swan, T. (1956), 'Economic Growth and Capital Accumulation', Economic Record 32(63): 334-61. 